\title{
First report of anthracnose lesions caused by Colletotrichum siamense on Annona scleroderma fruits in Mexico
}

\author{
Alejandro Salinas-Castro ${ }^{1,2}$ - Librado Vidal-Hernández ${ }^{2} \cdot$ Nayelli Ayatzol Vidal-Martínez $^{2}$. \\ Luis Fernando García-Barcenas ${ }^{1}$ • María de Jesús Yáñez-Morales ${ }^{3}$
}

Received: 3 October 2018 / Accepted: 3 September 2019/Published online: 11 September 2019

(C) Società Italiana di Patologia Vegetale (S.I.Pa.V.) 2019

Keywords Black lesions · Fruit mummification · Wild tree

Annona scleroderma Safford (Annonaceae family) is a Mexican perennial wild fruit tree. Anthracnose fruit lesions and mummification were observed in rainy season with $40 \%-80 \%$ incidence. In November 2014, in Veracruz region (19.3805833 N, $96.8416111 \mathrm{~W}) 15$ symptomatic fruits were collected from five random trees. Two tissue pieces were taken from the edge of one lesion per fruit. Thirty tissue samples were surface-disinfected with $70 \%$ ethanol (3 min), $4 \%$ sodium hypochlorite $(1 \mathrm{~min}$ ) and rinsed three times with sterile distilled water. Samples were dried, plated on chloramphenicol-amended (50 ppm) Potato Dextrose Agar Petri plates, and dark-incubated 8 days at $28^{\circ} \mathrm{C}$. Cotton-like colonies changed from white to pale salmon to brownish; the undersides of colonies were pale salmon to brownish and yellowish. Conidiomata, without setae, were yellowish to salmon. Conidia were fusiform, some oblong, 8-15 $(-17) \times(3-) 4(-4.5) \mu \mathrm{m}$ and guttulate. Appressoria were with germ pores, ovoid and slightly irregular, $6-8 \times 5 \mu \mathrm{m}$, and brown. Sexual stage was absent. Morphological characters allowed for Colletotrichum siamense Prihastuti, L. Cai \& K.D. Hyde identification (Prihastuti et al. 2009). Sequencing of ACTIN (512F/783R), GAPDH (GDF/GDR) and $\beta$-tubulin (Bt2) genes (Weir et al. 2012) confirmed morphological identification. Sequences (GenBank accession Nos. MK393450,

María de Jesús Yáñez-Morales

yanezmj@colpos.mx

1 Centro de Investigación en Micología Aplicada, Universidad Veracruzana, Médicos 5, Unidad del Bosque, CP 91010 Xalapa-Veracruz, México

2 Facultad de Ciencias Agrícolas, Campus Xalapa, Universidad Veracruzana, Circuito Gonzalo Aguirre Beltrán S/N, Zona Universitaria, CP 91190 Xalapa-Veracruz, México

3 Colegio de Postgraduados - Campus Montecillo, Fitopatología, km. 36.5 Carretera México-Texcoco, Texcoco 56230, State of Mexico, México
MK393451, MK393452) showed 98.3\%-99.5\% identity with C. siamense (the ex-holotype culture in ICMP18578) sequences at NCBI (FJ907423, JX009924, JX010404). Pathogenicity was tested on four disinfected, detached, unwounded fruits sprayedinoculated with a $5 \times 10^{4}$ conidia/ml suspension. Control fruits were sprayed with sterile water. Fruits were incubated at $80 \%$ relative humidity and $25^{\circ} \mathrm{C}$ for 7 days. Anthracnose symptoms appeared, and the fungus was re-isolated. The specimen CMCNRG\#0625 was deposited in the National Center for Genetic Resources (Mexico). This might be the first report of C. siamense causing anthracnose lesions on A. scleroderma fruits in Mexico (Farr and Rossman 2019).

\section{References}

Farr DF, Rossman AY (2019) Fungal Databases, U.S. National Fungus Collections, ARS, USDA (Retrieved May 15, 2019 from https://nt. ars-grin.gov/fungaldatabases/)

Prihastuti H, Cai L, Chen H, McKenzie EHC, Hyde KD (2009) Characterization of Colletotrichum species associated with coffee berries in northern Thailand. Fungal Divers 39:89-109

Weir BS, Johnston PR, Damm U (2012) The Colletotrichum gloeosporioides species complex. Stud Mycol 73:115-180

Publisher's note Springer Nature remains neutral with regard to jurisdictional claims in published maps and institutional affiliations. 